\title{
An exploration study on factors influencing green marketing
}

\author{
Naser Azad", Sina Nobahari, Hamid Bagheri, Mojtaba Esmaeeli and Mohammad Rikhtegar
}

Department of Management, Islamic Azad University, South Tehran Branch, Tehran, Iran

\begin{tabular}{l}
\hline C H R O N I C L E \\
\hline Article history: \\
Received January 12, 2013 \\
Received in revised format \\
15 April 2013 \\
Accepted 16 April 2013 \\
Available online \\
April 172013 \\
\hline Keywords: \\
Factor analysis \\
Green marketing \\
Critical factors
\end{tabular}

\section{A B S T R A C T}

\begin{abstract}
These days, there have been tremendous efforts on offering products, which are environment friendly. Green marketing plays an important role for attracting new customer and customer retention. This paper presents an empirical investigation based on the implementation of factor analysis to locate important factors influencing green marketing planning and strategies. building market oriented business units. The study designs a questionnaire including 23 questions and the questionnaire was distributed among 200 people who were visiting organic product exhibition. Cronbach alpha was calculated as 0.845 , which is well above the minimum acceptable limit and validates the results. The results of factor analysis reveal four major factors including green labeling, compatibility, product value and marketing component and size.
\end{abstract}

\section{Introduction}

During the past few years, there have been tremendous efforts on developing products, which are more environments friendly and there are literally various efforts on green marketing planning (Liu et al., 2012). Chan et al. (2012), for instance, aimed at reflecting the most recent advances on green industrial marketing, green/sustainable supply chains and their interplay in green industrial branding. Sharma, and Iyer (2012) reported that the innovation process relies primarily on frugal engineering that reduces material use and meets green marketing objectives at much lower. Rex and Baumann (2007) reported that green marketing could learn from conventional marketing in discovering other tools than labeling to promote green products. Addressing a wider range of consumers, working with the positioning strategies of price, place and promotion and actively engaging in market creation were given just as examples of their survey.

\footnotetext{
*Corresponding author.

E-mail addresses: dr.naserazad@yahoo.com (N. Azad)

(c) 2013 Growing Science Ltd. All rights reserved. doi: 10.5267/j.msl.2013.04.013
} 
Siriwardena et al. (2012) evaluated the effectiveness of an eco-marketing campaign on purchases of 'green' vehicles and reported that green-car buyers come from highly educated communities and age had a positive but non-linear effect on green car sales. Polonsky (2011) argued that green marketing had not achieved its potential for improving the quality of life of consumers, while improving the natural ecosystem. They discussed why different groups had had difficulties in embracing environmental issues, thus impeding real transformative green marketing from occurring. They concluded that making some changes could help marketers operationalize transformative green marketing.

Lee and Huang (2011) proposed the implementation of recommender systems to help the green shopping process and to help green consumerism. In their study, the architecture of a recommender system for green consumer electronics was presented. Customers' decision making process was modeled with an adaptive fuzzy inference system in which the input variables were the degrees of price, feature, and greenness and output variables were the estimated rating data. The whole architecture contained three types of recommendation including information filtering, candidate expansion, and crowd recommendation.

Ad hoc customization could be used to tune the recommendation results and their findings were reported in two categories. The first part explained the potentials of using recommender systems in green marketing and the promotion of green consumerism while the second part explained the proposed recommender system architecture using green consumer electronics as the context. Their second proposed architecture provided a capable platform for personalized green marketing by offering customers shopping advices tailored to their preferences and for the promotion of green consumerism.

Lee and Lam (2012) presented a sustainable industrial marketing framework of latest requirement of green and sustainable operation. They investigated how manufacturers could identify the problem of reverse logistics; design and develop of sustainable product and service by enhancing the efficiency of operations, and market competencies that add value to their customers' business processes. Green Jr. et al. (2012) reported that alignment of the marketing strategies by the partners throughout the supply chain was positively associated with supply chain performance and that supply chain performance was positively associated with organizational performance. They suggested that managers looking for improving the performance of their organizations should work with supply chain partners to align marketing strategies throughout entire the supply chain. Kumar et al. (2012) reviewed and explained different components of marketing strategy and sustainability, discussed evolution of sustainability in marketing strategy and lastly and discussed the future of sustainability marketing strategy.

In this paper, we present an empirical investigation to study the effects of different factors on green marketing planning. The organization of this paper first presents details of proposed study in section 2 while the results of applying factor analysis are given in section 3 and finally concluding remarks are given in the last to summarize the contribution of this paper.

\section{The proposed study}

The proposed study of this paper attempts to detect important factors impacting on green marketing using factor analysis. The study designed a questionnaire, distributed among 200 customers who participated in organic product exhibition. The proposed study of this paper uses factor analysis to extract important factors. The questionnaire consists of 23 questions and since factor analysis is sensitive on skewness of data, we have decided to remove some of the questions and use only 18 questions for final survey. 
Cronbach alpha was calculated as 0.845 , which is well above the minimum acceptable limit and validates the results. Kaiser-Meyer-Olkin Measure of Sampling Adequacy has been calculated as 0.835 and Bartlett's test of Sphericity approximation Chi-Square has also been calculated as 815.733, which validate the overall results.

\section{The results}

The proposed study of this paper has determined four major factors using factor analysis and in this section, we present details of our findings.

\subsection{The first factor: Green labeling}

The first factor, "Green labeling” includes four components including "simplicity of detecting green product", "Being understandable", "Sufficient information on labels" and "Relativity of information". Table 1 summarizes details of our findings on this factor.

\section{Table 1}

The summary of factors associated with green labeling

\begin{tabular}{lcccc}
\hline \multicolumn{1}{c}{ Option } & Factor weight & Eigenvalue & \% ofvariance & Accumulated \\
\hline Simplicity of detecting green product & .715 & & & \\
Being understandable & .678 & & & \\
Sufficient information on labels & .764 & 5.123 & 28.463 & 28.463 \\
Relativity of information & .615 & & & \\
\hline
\end{tabular}

It is evident from the results of Table 1 that "Sufficient information on labels" is number one priority followed by "simplicity of detecting green product", "Being understandable" and "Relativity of information". Cronbach alpha has been calculated as 0.713 , which validates the results of our survey.

\subsection{The second factor: Compatibility}

Compatibility is an essential factor and plays important role for the success of any marketing planning including green management. This factor includes five factors including "Important information on labels", "Capability of building emotional relationship with customers", "Importance of recyclable products", "Trust to green product" and "Green packaging” and the results of factor analysis have been summarized in Table 2 as follows,

\section{Table 2}

The summary of factors associated with compatibility

\begin{tabular}{lcccc}
\hline Option & Factor weight & Eigenvalue & \% ofvariance & Accumulated \\
\hline Important information on labels & .642 & & & \\
Capability of building emotional & .556 & & & \\
relationship with customers & .594 & & & \\
Importance of recyclable products & .458 & & & \\
Trust to green product & .691 & 2.013 & 11.19 & 39.468 \\
\hline Green packaging & & &
\end{tabular}

According to the results of Table 2, "Green packaging" is the most important factor followed by "Important information on labels", "Importance of recyclable products" while "Trust to green product” is the last priority. 


\subsection{The third factor: Value of product}

Value of product is the third important factor influencing green marketing and it contains four factors including "being attractive”, “Catching customers' eyes”, "Suitability” and "Availability of good reason for paying more on green products". Table 3 shows details of our survey. The results of Table 3 clearly show that "Availability of good reason for paying more on green products" plays essential role on marketing green products followed by "Suitability".

\section{Table 3}

The summary of factors associated with value of product

\begin{tabular}{lcccc}
\hline Option & Factor weight & Eigenvalue & \% ofvariance & Accumulated \\
\hline Being attractive & .578 & & & \\
Catching customers' eyes & .590 & & & \\
Suitability & .744 & & \\
$\begin{array}{l}\text { Availability of good reason for paying more on } \\
\text { green products }\end{array}$ & .788 & 1.352 & 7.508 & 47.157 \\
\hline Cronbach alph $=0.719$ & & & \\
\hline
\end{tabular}

\subsection{The fourth factor: Green advertisement components}

Green advertisement components is the last factor, which influences development of creating new businesses and it includes five factors summarized in Table 4 as follows,

\section{Table 4}

The summary of factors associated with green advertisement components

\begin{tabular}{lcccc}
\hline Option & Factor weight & Eigenvalue & $\%$ ofvariance & Accumulated \\
\hline Advertisement aided green purchasing & .677 & 1.16 & 6.444 & 53.6 \\
The relative importance of green products & .574 & & & \\
Media advertisement on green products & .503 & & & \\
Customer satisfaction from organic product & .507 & & \\
Exaggeration on marketing green products & .578 & & \\
\hline Cronbach alph $=0.673$ & & &
\end{tabular}

Based on the results of Table 4, “Advertisement aided green purchasing” is the most important factor followed by "Exaggeration on marketing green products" and "The relative importance of green products”.

\section{Discussion and conclusion}

In this paper, we have presented an empirical investigation based on the implementation of factor analysis to detect important factors influencing green marketing planning. The results of factor analysis have revealed four major factors including green labeling, compatibility, value of product and green advertisement components.

The first factor, "Green labeling" includes four components including "simplicity of detecting green product", "Being understandable", "Sufficient information on labels" and "Relativity of information". In our survey, "Sufficient information on labels" was number one priority followed by "simplicity of detecting green product”, "Being understandable” and "Relativity of information”. Compatibility was an essential factor and plays important role for the success of any marketing planning including green management. This factor included five factors including "Important information on labels", "Capability of building emotional relationship with customers", "Importance of recyclable products", "Trust to green product" and "Green packaging”. In our survey, "Green packaging" is the most important factor followed by "Important information on labels", "Importance of recyclable products" while "Trust to green product" is the last priority. 
Value of product has been the third important factor influencing green marketing and it contained four factors including "being attractive", "Catching customers' eyes", "Suitability" and "Availability of good reason for paying more on green products". The results of our survey have indicated that "Availability of good reason for paying more on green products" played essential role on marketing green products followed by "Suitability". Finally, Green advertisement components was the last factor, which influences development of creating new businesses and it includes five factors and in our survey "Advertisement aided green purchasing" was the most important factor followed by "Exaggeration on marketing green products" and "The relative importance of green products". Based on the results of our survey, we can present the following framework for our study.

\begin{tabular}{l}
\hline $\begin{array}{l}\text { Green labeling: "simplicity of detecting green product", "Being } \\
\text { understandable”, "Sufficient information on labels" and } \\
\text { "Relativity of information" }\end{array}$ \\
$\begin{array}{l}\text { Compatibility: "Important information on labels", "Capability of } \\
\text { building emotional relationship with customers", "Importance of } \\
\text { recyclable products", "Trust to green product" and "Green } \\
\text { packaging" }\end{array}$
\end{tabular}

Value of product: "being attractive”, “Catching customers’ eyes”, "Suitability" and "Availability of good reason for paying more on green products"

Green advertisement components: "Advertisement aided green purchasing", "Exaggeration on marketing green products" and "The relative importance of green products"

Fig. 1. The structure of the proposed model

\section{Acknowledgment}

The authors would like to thank anonymous referees for constructive comments on earlier version of this paper.

\section{References}

Chan, H.K., He, H., Wang, W.Y.C. (2012). Green marketing and its impact on supply chain management in industrial markets. Industrial Marketing Management, 41(4), 557-562.

Green Jr., K.W., Whitten, D., \& Inman, R.A. (2012). Aligning marketing strategies throughout the supply chain to enhance performance. Industrial Marketing Management, 41(6), 1008-1018.

Kumar, V., Rahman, Z., Kazmi, A.A., \& Goyal, P. (2012). Evolution of Sustainability as Marketing Strategy: Beginning of New Era. Procedia - Social and Behavioral Sciences, 37, 482-489

Lee, Y.L., \& Huang, F.H. (2011). Recommender system architecture for adaptive green marketing. Expert Systems with Applications, 38(8), 9696-9703.

Lee, C.K.M. \& Lam, J.S.L. (2012). Managing reverse logistics to enhance sustainability of industrial marketing. Industrial Marketing Management, 41(4), 589-598

Liu, S., Kasturiratne, D., \& Moizer, J. (2012). A hub-and-spoke model for multi-dimensional integration of green marketing and sustainable supply chain management. Industrial Marketing Management, 41(4), 581-588. 
Polonsky, M.J. (2011).Transformative green marketing: Impediments and opportunities. Journal of Business Research, 64(12), 1311-1319.

Rex, E., \& Baumann, H. (2007). Beyond ecolabels: what green marketing can learn from conventional marketing. Journal of Cleaner Production, 15(6), 567-576

Sharma, A., \& Iyer, G.R. (2012). Resource-constrained product development: Implications for green marketing and green supply chains. Industrial Marketing Management, 41(4), 599-608.

Siriwardena, S., Hunt, G., Teisl, M.F., \& Noblet, C.L. (2012). Effective environmental marketing of green cars: A nested-logit approach. Transportation Research Part D: Transport and Environment, 17(3), 237-242 